\title{
THE RELATION BETWEEN ISLAMIC EDUCATION ENVIRONMENT MANAGEMENT AND STUDENT EMOTIONAL INTELLIGENCE
}

\section{Eliana Sari}

State University of Jakarta (UNJ)

Jl. Rawamangun Muka, Jakarta Timur

Email: briant_ramadhan@yahoo.com

\begin{abstract}
This study aims to find out the degree of the relationship between the implementation of Islamic education management of school environment and students' emotional intelligence. The theory underlying in this study is the management of school environment ( $\mathrm{Ki}$ Hajar Dewantara), and emotional intelligence (Shapiro and Goleman). This study used correlational study. Respondents were female students of Islamic educational institutions in Bekasi City, West Java, Indonesia. The result shows that the relation degree between the implementation of the management of Islamic education of school environment and students' emotional intelligence is quite significant $(0,907 \%)$. This means that if the management of Islamic education of school environment enhances effectively, the implementation of one percent of students' emotional intelligence will increase by 0 , $907 \%$. This study also finds that the management of Islamic education of school environment can be a preventive and anticipatory solution for students' deviant behaviors.
\end{abstract}

Keywords: Islamic Education Management, school environment, emotional intelligence

\begin{abstract}
ABSTRAK
Penelitian ini bertujuan mengetabui seberapa besar bubungan antara penerapan manajemen pendidikan Islam di lingkungan sekolah dengan kecerdasan emosional peserta didik. Teori yang melandasi penelitian ini adalah manajemen lingkungan sekolah (Ki Hajar Dewantara), dan kecerdasan emosional (Shapiro dan Goleman). Metode penelitian yang digunakan adalah studi korelasional. Subyek penelitian adalah siswi lembaga pendidikan Islam di Kotamadya Bekasi, Jawa Barat, Indonesia. Hasil penelitian menunjukkan bahwa hubungan antara penerapan manajemen pendidikan Islam di lingkungan sekolah dengan kecerdasan emosional peserta didik cukup signifikan (sebesar 0.907\%). Berarti, jika manajemen pendidikan Islam di lingkungan sekolah ditingkatkan keefektifan pelaksanaannya sebesar satu persen maka kecerdasan emosional peserta didik akan meningkat sebesar 0.907\%. Hasil penelitian pun menjawab bahwa manajemen pendidikan Islam di lingkungan sekolab bisa menjadi solusi preventif dan antisipatif atas perilaku menyimpang peserta didik.
\end{abstract}

Kata Kunci: Manajemen Pendidikan Islam, lingkungan sekolah, kecerdasan emosional 


\section{INTRODUCTION}

The increasing violation on religious norms and laws made by the young people of school ages in Indonesia in the last five years rises concerns formost Indonesian adults, especially teachers and education personnels. Some cases of criminal acts, violent and immoral behaviours that have occurred include; 1) the finding of verbal and physical torture videos performed by unscrupulous learners of Junior High School, SMP 16 Bandar Lampung. In the video it shows 15.17 seconds of violence and inappropriate diatribe spoken by school-age children (Regional Kompas, June 10, 2011); 2) Three high school students arrested for stealing money USD 5 million in Medan, North Sumatra. Students who do stealing are not found once. Several cases of theft among adolescents are not triggered by wanting to earn money per se, but by a matter of prestige as well. For example, Yoyo, a vocational high school student in Cimahi, Bandung, West Java desperately stole a motorcycle because he wanted "showing-off" himself on the streets (SCTV Liputan 6 Online). Brawl among students of High Schools of SMAN 70 and SMAN 6 Jakarta on Monday, September 24th, 2012 has made the killing Alawy Yusianto Son. An investigation found that there were two causes of brawl; 1) brawl is a culture of the schools, it has been inherited from their seniors; 2), students have a certain area boundaries so that the encroachment to their authority could directly trigger the brawl (Megapolitan Kompas Online, Oct 01, 2012).

Data Protection Commission Bureau noted during the first quarter of 2012 that there has been occurred 2008 cases of crimes committed by students (Hizbut Tahrir Online, August 26, 2012). The data service was recorded through a public complaint Hotline Service consisted ofin-person direct complaints, phone calls, or electronic correspondence; moreover, in the whole year 2011 the National Commission for Children Protection received reports for 2.386 cases of violence. This number was increased by $98 \%$ when it compared with the public complaints received by National Commission for Children Protection in 2010, amounted to 1,234 complaints (Komnas Perlindungan Anak Online, December 21, 2011).

Above facts indicate that there is something going on with young generation/Indonesian students. They tend to be aggressive even destructive. They become emotional individuals who are arrogant, unwilling to negotiate, less humane, unsymphatetic and untoughtful. The characters of young people tend to be high aggressive, especially when they are in the time of building their own selves, although the process of being self is often harmful to others.

Since Indonesia got independence, the education system has been built. Various curricula has been implemented and continued to develop in 
the direction of improvement. It has been all intended solely for the achievement of educational goals of building intellectual life of Indonesian. In Article 1 of the Law of the National Education System No. 20 in 2003, education isaimed to implement conscious and deliberate efforts of creating a learning atmosphere result in effective learning process in order that learners actively develop their potentials achieving spiritual strength of religious, selfcontrol, personality, intelligence, noble characters, and skills, those needed to themselves, community, the state and the nation. Education should serve to make people to become civilized and have skills of natural selection for their whole lives experienced in this world.

Although the process of implementing education and efforts of improving it for perfection has been running since Indonesia's Independence (1945), deviant behavior of learners never stop, it even tends to increas, and become more common in recent years. There is something wrong with the education system in Indonesia, maybe the system, curriculum or educational management. Finding the cause of the ineffectiveness of the educational process in Indonesia. Indeed, it requires a comprehensive and substantive research. Examples of the above cases indicate that at least one of the underlying causes of violence, aggressiveness and destructivity students is low emotional intelligence learners.

One of the factors that influence the development of one's emotional intelligence is the environment. Environment allegedly is the most powerful factor affecting the development of someone's emotional intelligence, good family environment, school and community. In the context of education, Ki Hajar Dewantara in La Sulo (2005, p. 45) states that the family, school and community is a single triple education center. All three are different but the environment is an integral and inseparable component that contributes greatly to the formation of a person's behavior. Single triple education center or understood as an educational environment can be interpreted as all the elements that involve directly or indirectly in educational process. Environmental education which covers all aspects are required in educational process, both in the form of the physical environment and social environment. Therefore, theoretically, environmental education is an important element that directly affects the success of the process and purpose of education.

This study aims to determine the degree of the relationship between management of Islamic education at the school environment and the emotional intelligence of students. Thus, there are three theories underlie this study; 1) the management of Islamic education; 2) the school environment; and 3) emotional intelligence. 
Management of Islamic education is emphasized more on process rather than outcomes. This means that Islam emphasizes on management of education process which is an important part of success of achieving educational goals; unlike the management of education in general which tend to be oriented at the final destination forits indicator of success of achieving educational goals. Management of Islamic education has different characteristics to that of the management of public education, as it is included on basis of revelation, putting on a backrest that is theological, rational, empirical and theoretical, patternalizing theo anthrophocentric, developing emancipatory mission, transformative mechanism, processing personality formation, and integrating Muslim spiritual maturity (faith), building intellectual, charity, skills and morals (Qomar, 2007, p. 45). Therefore, the management of Islamic education is not free from the spirit of Islamic education that teaches Islam. The essence of the teachings of Islam isdirected to create prosperity in the world and the Hereafter (rabbana ätina fi al-dunya hasanah wa fi al-äkbirati hasanah). Operational direction is to actualize the full potentials of self that include changes in attitude, appearance and outlook of human life straightly and truthfully (as-siräth al-mustaqim).

\section{Formulation Purpose of Islamic Education (PAI)}

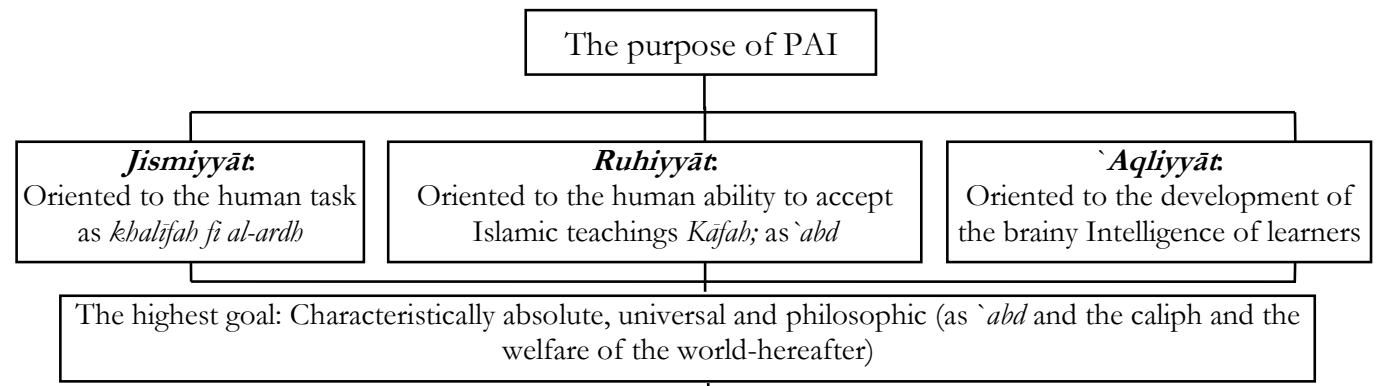

The general objective: the empirical-realistic characteristically, giving operational direction actualized in all the potential including a change in attitude, appearance and outlook

Specific Objectives: Characteristically-adaptive elastic, shape the operationalization of the highest purpose and general purpose

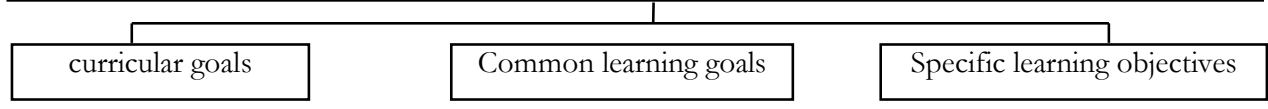

(Nizar in Nasih, 2001, p. 8)

In any educational process educational environment serves as; 1) personal coaching in efforts to maintain the culture; 2) teaching in an effort to the prevalence of acquisition of knowledge; and 3) training in an effort of skill improvement or often in referance to a single triple educational activities. More specifically, the educational environment also serves to; a) help learners interaction with the environment (both physically, socially); b) 
teach general behavior; and c) select or prepare people to perform certain functions (Tirtarahardja, 2000, p. 25). Specification of environmental education is the school environment.

The role of school environment is greatly to form learners behavior, because the school teaches moral, ethical, religious and aesthetic materials, and to preserve cultural heritage that exists in the community while teaching the culture to students. School environment also serves to help parents train their children good habits as well as manners, provides education for people whose lives are not or hardly taught by parents at home, and teach children to acquire skills of writing, reading, arithmetic, drawing and other sciences that are able to develop the knowledge and intelligence.

The function of the school environment will be actualized if the management of education in the school environment is also implemented well and correctly. Management education in the school environment is a systematic and comprehensive effort that involves planning, organizing, implementing and controling of all elements that influence directly or indirectly to the success of the educational process. It can be implemented by applying 18 indicators of character education at schools starting from one element to another element in the classroom.

One of those indicators is to grow religious behavior. In the context of the management of Islamic education, religious behavior is explained by the teachings of Islam, the Qur'an and Hadith. For example, to instill religious behavior, school elements can perform activities in the form of celebration of religious holidays in Islam, providing ritual facilities that can accommodate the entire school community, and providing an opportunity for all citizens to practice their religion at schools. Application of Islamic education in environmental management class can be done by performing pray together before starting lessons or doing tadarrusan (Qur'anic recitation) completed by reading the meaning of the verses in order to get better understanding on the contentsof the Holy Qur'an. Building honesty can be implemented through the provision of a canteen, where students are urged to hand over the goods that do not belong to them in the case they find something and enable them to provide a place and put the belongings of others at appropriate places. The same treatment to all learners and no discriminatory in any reasons should also be applied, discipline is built, empathy and support to each other should be taken progressively to all parties at schools.

Emotional intelligence which is the ability possessed by human beings should be implemented in order that students are able to manage themselves and others. Having visible concrete forms of emotional behavior is to able to refrain (patient) on a condition that is not comfortable for students and building empathy (caring) about the condition of other people who are in 
distress. Psychologists Salovey and Mayer explain well about emotional intelligence as a subset of social intelligence that involves the ability to monitor social feelings that involve the ability of understanding others, sort through it all and use the monitoring to guide the mind and action (Shapiro, 1998, p. 17). Shapiro explains that the nature of emotional intelligence is not settled, it can vary depending the circumstances surrounding a person. Goleman (1999, p. 38) defines emotional intelligence as a person's ability to motivate oneself, endure frustration, impulse control (on impulsive needs), no over estimation toward the pleasure or pain, it enables to manage reactive needs, keeping stress-free, no crippling in the ability of thinking, empathizing others as well as the principle of trial and pray. Emotional intelligence should build students to have the ability to control impulses (aggressiveness) into positive thoughts and feelings of empathy to others that would methodology cultivate love from one to another among learners.

Based on the concept of environment, this study is a research field. It used quantitative descriptive correlational study techniques, in which according to Consuelo in Umar (1999, p. 24), it is noted that the research of correlation (correlational study), is a study designed to determine the degree of correlation of different variables in a population.

Subjects of this study were students of Islamic educational institutions located in the Municipality of Bekasi, West Java. The sampling technique used in this study is non-probability sampling technique with judment sampling approach. Judment sampling approach is an approach to sampling by using certain criteria, namely students who study in Islamic educational institutions witha minimum duration one year and more. The samples used in this study were 100 students represented by students from Islamic institutions and Nubda Därul Kiräm Al Mansyüriyah which organize basic education (primary level of Madrasah and Islamic Junior High School) in the Municipality of Bekasi. The sample selection of two (2) educational institutions is based on analysis and consideration for this researcher, both Islamic educational institutions are considered to represent students of Islamic educational institutions that exist in the region Municipality of Bekasi.

In this study, there are two variables studied: independent variable or $\mathrm{Y}$ which is emotional intelligence and dependent variable or $\mathrm{X}$ which is the management of Islamic education. Here,the researcher analyzed the influence of Islamic education management at the school environment on students' emotional intelligence. Setting on the scope of the topic, this study used statistical formula, from which the researcher drew conclusion developed from the results of the analysis and discussion of the research data. Data collection techniques used in this study used the technique of communication by distributing questionnaires and the type of data is the type 
of primary data. Data analysis techniques in this study using descriptive and quantitative analysis, in which the descriptive analysis using average analysis and Likert scale. Analysis of Likert scale used is as follows: Strongly Agree (ST): 5, Agree (S): 4, Neutral (RR): 3, Less Agree (KS): 2, Disagree (TS): 1, the interval of $=(5-1) / 5=0.8$, the value Likert scale is: $1.00-1.80$ : Disagree (TS), 1.81 - 2.60: Less Agree (KS), 2.61 - 3:40: Neutral (RR), 3:41 to 4:20: agree (S), 4:21 to 5:00: Strongly Agree (ST). Prior to the questionnaire distributed at the field research, the researcher did firstly its validity and reliability testing.

Validity testing is done to determine whether each statement item is a relevant variable or not. In other words the statement items are representative to the relevant variables. Testing the reliability of the variables of Islamic education management and emotional intelligence is aimed to determine whether the items selected statement has validity or sharpness of measuring these variables, as well as testing the classical assumption for the use of simple regression analysis tools that test for normality. Meanwhile, to determine the effect of Islamic education management to students' emotional intelligence used simple regression analysis which is: $\mathrm{Y}=\alpha+\beta \mathrm{X}$, wherein: $\mathrm{Y}$ is emotional intelligence and $\mathrm{X}$ is the management of Islamic education. Simple regression analysis is performed after testing the normality of the data distribution using a scatter plot of the model first.

\section{FINDINGS AND ANALYSIS}

\section{Findings}

\section{Validity Test Results}

The results of testing the validity of Islamic education management variables consists of eight dimensions of the Qur'anic revelation and the Hadith ( $\mathrm{x} 1$, $\mathrm{x} 2, \mathrm{x} 3, \mathrm{x} 4, \mathrm{x} 5)$, patterned theoanthrophocentric (x6, x7, x8, x9, x10), the development of emancipatory ( $111, \mathrm{x} 12, \mathrm{x} 13, \mathrm{x} 14)$, transformative mechanism (x15, x16, x17, x18, x19), Muslim personality (x20, x21, x22, x23), maturity IQ, SQ, and EQ (x24); backrest theological, rational, empirical and theoretical (x25); and considered by culture (x26), shows that for all the items statements of each dimension is valid because the value of corrected itemtotal correlation above 0360 . The validity of the calculation results with SPSS 18 software tools, are as follows:

\section{Results of Validity Test for Variable Islamic Education Management}

\begin{tabular}{|c|c|c|c|c|}
\hline Variable & Dimention & Item & $\begin{array}{c}\text { Corrected item- } \\
\text { total correlation }\end{array}$ & Explanation \\
\hline Islamic & Scripture and Hadist & $\mathrm{X} 1$ & 0.916 & Valid \\
\cline { 2 - 5 } $\begin{array}{c}\text { Education } \\
\text { Management }\end{array}$ & & $\mathrm{X} 2$ & 0.976 & Valid \\
\cline { 2 - 5 } & & $\mathrm{X} 3$ & 0.976 & Valid \\
\hline
\end{tabular}




\begin{tabular}{|c|c|c|c|}
\hline & $\mathrm{X} 4$ & 0.952 & Valid \\
\hline & X5 & 0.952 & Valid \\
\hline \multirow{5}{*}{$\begin{array}{c}\text { Theoanthropocentric } \\
\text { Type }\end{array}$} & $\mathrm{X} 6$ & 0.958 & Valid \\
\hline & $\mathrm{X} 7$ & 0.989 & Valid \\
\hline & $\mathrm{X} 8$ & 0.989 & Valid \\
\hline & $\mathrm{X} 9$ & 0.896 & Valid \\
\hline & $\mathrm{X} 10$ & 0.949 & Valid \\
\hline \multirow{4}{*}{$\begin{array}{l}\text { Emancipatoric } \\
\text { Development }\end{array}$} & $\mathrm{X} 11$ & 0.933 & Valid \\
\hline & $\mathrm{X} 12$ & 0.846 & Valid \\
\hline & $\mathrm{X} 13$ & 0.967 & Valid \\
\hline & $\mathrm{X} 14$ & 0.878 & Valid \\
\hline \multirow{5}{*}{$\begin{array}{c}\text { Transformative } \\
\text { Mechanism }\end{array}$} & $\mathrm{X} 15$ & 0.950 & Valid \\
\hline & $\mathrm{X} 16$ & 0.878 & Valid \\
\hline & $\mathrm{X} 17$ & 0.867 & Valid \\
\hline & $\mathrm{X} 18$ & 0.900 & Valid \\
\hline & $\mathrm{X} 19$ & 0.917 & Valid \\
\hline \multirow{4}{*}{$\begin{array}{c}\text { Muslim } \\
\text { Character/Akblāq }\end{array}$} & $\mathrm{X} 20$ & 0.886 & Valid \\
\hline & $\mathrm{X} 21$ & 0.948 & Valid \\
\hline & $\mathrm{X} 22$ & 0.942 & Valid \\
\hline & $\mathrm{X} 23$ & 0.946 & Valid \\
\hline $\begin{array}{c}\mathrm{IQ}, \mathrm{SQ}, \text { and EQ } \\
\text { Maturation }\end{array}$ & $\mathrm{X} 24$ & 0.955 & Valid \\
\hline $\begin{array}{l}\text { Basis of theology, } \\
\text { rational, empirics dan } \\
\text { theory }\end{array}$ & $\mathrm{X} 25$ & 0.868 & Valid \\
\hline Recognizing the culture & $\mathrm{X} 26$ & 0.980 & Valid \\
\hline
\end{tabular}

Source: result of questionnaire data process

Results of testing the validity of the variables of emotional intelligence consists of five dimensions that identify emotions (y1, y2, y3, y4, y5), managing emotions (y6, Y7, Y8, Y9, Y10, y11), motivating oneself (Y12, y13, Y14, Y15, y16, y17, Y18), managing emotions in others (Y20, Y21, Y22, y23), and collaboration with others (y24, y25, Y26, Y27, Y28, y29), showing all statement items of dimension identify emotions, managing emotions, motivating oneself, recognizing emotions in others, and building relationships with other people is valid because the value of corrected itemtotal correlation is over 0360 , while the items on the statement that has the dimensions of self-concept, there are two statement items which are invalid because the value of the item-total correlation corrected under 0360, ie y1 and y5 statement items. The validity of the calculation results using SPSS 18 software tools are as follows:

The Results of Validity Test for the variables emotional intelligence

\begin{tabular}{|c|c|c|c|c|}
\hline Variable & Dimension & grain & $\begin{array}{c}\text { Corrected item- } \\
\text { total correlation }\end{array}$ & Description \\
\hline Emotional & Recognizing emotions & Y1 & -0.122 & Not Valid \\
\hline
\end{tabular}


Eliana Sari

\begin{tabular}{|c|c|c|c|c|}
\hline \multirow[t]{28}{*}{ intelligence } & \multirow{5}{*}{ Managing emotions } & $\mathrm{Y} 2$ & 0.882 & Valid \\
\hline & & Y3 & 0.791 & Valid \\
\hline & & Y4 & 0.882 & Valid \\
\hline & & Y5 & 0.050 & Not Valid \\
\hline & & Y6 & 0.992 & Valid \\
\hline & & $\mathrm{Y7}$ & 0.992 & Valid \\
\hline & & Y8 & 0.937 & Valid \\
\hline & & Y9 & 0.937 & Valid \\
\hline & & Y10 & 0.928 & Valid \\
\hline & & Y11 & 0.992 & Valid \\
\hline & \multirow[t]{7}{*}{ Motivating yourself } & Y12 & 0.963 & Valid \\
\hline & & Y13 & 0.948 & Valid \\
\hline & & Y14 & 0.952 & Valid \\
\hline & & Y15 & 0.948 & Valid \\
\hline & & Y16 & 0.903 & Valid \\
\hline & & Y17 & 0.966 & Valid \\
\hline & & Y18 & 0.891 & Valid \\
\hline & \multirow{5}{*}{$\begin{array}{l}\text { Recognizing emotions } \\
\text { in others }\end{array}$} & Y19 & 0.950 & Valid \\
\hline & & Y20 & 0.878 & Valid \\
\hline & & Y21 & 0.867 & Valid \\
\hline & & Y22 & 0.900 & Valid \\
\hline & & Y23 & 0.917 & Valid \\
\hline & \multirow{6}{*}{$\begin{array}{l}\text { Relationships with } \\
\text { others }\end{array}$} & Y24 & 0.928 & Valid \\
\hline & & Y25 & 0.908 & Valid \\
\hline & & Y26 & 0.954 & Valid \\
\hline & & Y27 & 0.939 & Valid \\
\hline & & Y28 & 0.954 & Valid \\
\hline & & Y29 & 0.954 & Valid \\
\hline
\end{tabular}

Source: Processed questionnaire

Reliability Test Results

The results of reliability testing with SPSS 18 software tools indicate that all dimensions of the variable management of Islamic education and emotional intelligence are reliable because there shows Cronbach alpha values higher than 0.70 , and the results are as follows:

\begin{tabular}{|c|c|c|c|}
\hline Variable & Dimention & $\begin{array}{c}\text { Value of } \\
\text { Cronbach } \\
\text { Alpha }\end{array}$ & Description \\
\hline \multirow{6}{*}{$\begin{array}{l}\text { Islamic } \\
\text { Education } \\
\text { Manageme } \\
\text { nt }\end{array}$} & Based on the Qur'anic revelation and Hadith & 0.985 & Reliable \\
\hline & Patterned Theoanthropocentric & 0.985 & Reliable \\
\hline & Developing emancipatory principles & 0.961 & Reliable \\
\hline & Developing transformative mechanism & 0.965 & Reliable \\
\hline & Building a Muslim personality & 0.972 & Reliable \\
\hline & Building maturity IQ, SQ, and EQ & 0.855 & Reliable \\
\hline
\end{tabular}




\begin{tabular}{|c|c|c|c|}
\hline & $\begin{array}{l}\text { Applying theological backrest, rational, } \\
\text { empirical and theoretical }\end{array}$ & 0.890 & Reliable \\
\hline & Considering the culture & 0.975 & Reliable \\
\hline \multirow{5}{*}{$\begin{array}{l}\text { Emotional } \\
\text { intelligence }\end{array}$} & Recognizing emotions & 0.725 & Reliable \\
\hline & managing emotions & 0.989 & Reliable \\
\hline & Motivating self & 0.983 & Reliable \\
\hline & Recognizing emotions of others & 0.965 & Reliable \\
\hline & Relationships with others & 0.982 & Reliable \\
\hline
\end{tabular}

Source: Processed questionnaire

Descriptive Analysis

The results showed that of the 100 respondents who responded to the ways of the implementation of Islamic education management in Islamic educational institutions in the Municipality of Bekasi and the degree of emotional intelligence of students at Islamic educational institutions in Bekasi municipality can be seen in Table. 3 follows (R_MPI = average score of Islamic education management and R_PNA = average score of emotional intelligence):

The average yield of learners perceptions of Islamic educational institutions against Islamic education management and emotional intelligence

\begin{tabular}{|l|c|c|c|c|}
\hline & $\mathrm{N}$ & Minimum & Maximum & Mean \\
\hline R_MPI & 100 & 2.00 & 5.00 & 3.7262 \\
\hline R_PNA & 100 & 2.07 & 4.93 & 3.7112 \\
\hline Valid N (listwise) & 100 & & & \\
\hline
\end{tabular}

Source: Data processed questionnaires

Based on the results of the calculation presented at table, the average score of Islamic education management amounted to 3.73 and in the category of agreed or in other words it can be said that the students who study in Islamic educational institutions in the Municipality of Bekasi stated that the application of Islamic education management has been positive. Score average value of emotional intelligence is at 3.71 which has the meaning that the emotional intelligence of students can demonstrate good performance or it can be said that the students are comfortable with the application of Islamic education management of Islamic educational institutions so that they can get a good emotional intelligence. Whereas to determine the effect of the environmental management of Islamic education at schools on emotional intelligence of students can use simple regression analysis. Before using simple regression tool, it is necessary to test the normality of the data distribution and normality test results using a scatter plot of the model as follows: 


\section{Test Results Using the Normal Distribution Graph.}

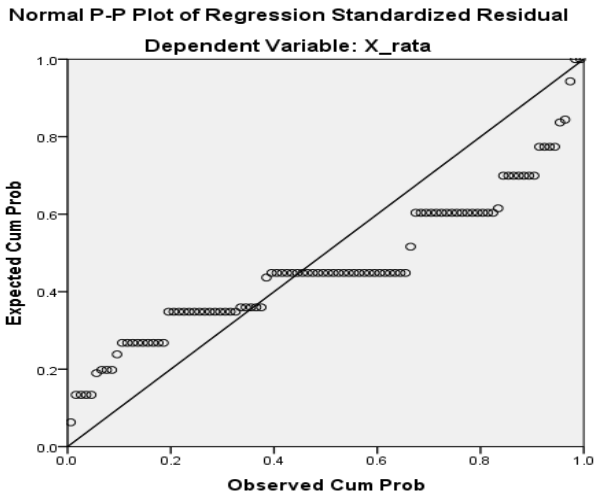

Based on test results of normal distribution using the graph, it can be concluded that because the data is not in normal distribution, data scattered around the diagonal line, therefore, to overcome this can be normal data distribution theory with the concept of the central limit theory of Bowerman (2010, p. 37) stating that if the number is greater analysis of data from 30 data, then the data is assumed to be normally distributed. Test results using a simple regression can be seen at the following table:

Results of Simple Regression Calculation ANOVA $^{\mathrm{a}}$

\begin{tabular}{|l|l|r|r|r|r|c|}
\hline \multicolumn{2}{|c|}{ Model } & $\begin{array}{c}\text { Sum of } \\
\text { Squares }\end{array}$ & df & Mean Square & F & Sig. \\
\hline \multirow{3}{*}{1} & Regression & 35.858 & 1 & 35.858 & 9636.474 & $.000^{\mathrm{b}}$ \\
\cline { 2 - 7 } & Residual & .365 & 98 & .004 & & \\
\cline { 2 - 7 } & \multicolumn{2}{|l|}{36.222} & 99 & & & \\
\hline \multicolumn{2}{|l|}{ Total Dependent Variable: R_PNA } \\
\multicolumn{2}{|l}{ b. Predictors: (Constant), R_MPI }
\end{tabular}

Source: Data processed questionnaires

Based on the calculation results showed at table. It is found the model for the influence of Islamic education management of the emotional intelligence can be formed significantly, because the value of the P-Value of 0000 and less than an alpha of 0.05 , thus the model can be used to predict the influence of Islamic education management to emotional intelligence. As for knowing how to influence the management of Islamic education to emotional intelligence can be seen from the t-test for variables Islamic education management and calculation results can be seen in table: 
Results of the $t$ test of simple regression

Coefficients $^{\mathrm{a}}$

\begin{tabular}{|l|l|r|r|r|r|r|}
\hline \multirow{2}{*}{ Model } & \multicolumn{2}{|c|}{ Unstandardized Coefficients } & \multicolumn{2}{|c|}{$\begin{array}{c}\text { Standardized } \\
\text { Coefficients }\end{array}$} & \multirow{2}{*}{ t } & \multirow{2}{*}{ Sig. } \\
\cline { 3 - 5 } \multicolumn{2}{|c|}{} & B & Std. Error & Beta & & \\
\hline \multirow{2}{*}{1} & (Constant) & .333 & .035 & & 9.518 & .000 \\
\cline { 2 - 6 } & R_MPI & .907 & .009 & .995 & 98.166 & .000 \\
\hline
\end{tabular}

a. Dependent Variable: R_PNA

Source: Data processed questionnaires

Based on calculations showed at table above, it can be explained that there is an influence of Islamic education management on emotional intelligence, namely by looking at the value of the P-Value of variable R_MPI of 0000 which is smaller than alpha 0:05. So it can be concluded that there is a positive and significant influence between management Islamic education on emotional intelligence and the model predictions are as follows:

$$
\text { R_PNA }=0333+0907 \text { R_MPI }
$$

Implications of the regression model is the better management of Islamic education in Islamic educational institutions in the Municipality of Bekasi, it can increase emotional intelligence of students. It means that if the Islamic educational institutions improve the effectiveness of Islamic education management by one percent it will be able to increase the emotional intelligence of students by 0907 percent.

\section{Analysis}

The findings of this study indicate that emotional intelligence of learners are influenced significantly by the management of Islamic education, and this is complementary with the opinion of Goleman (1999: 56) who speaks about the school environment as one of the factors that affect a person's emotional intelligence. Management of Islamic education in the school environment as measured through indicators: 1) On the basis of the Qur'anic revelation and Hadith, 2) patterned theoanthrophocentric, 3) Developing emancipatory principles, 4) Developing a transformative mechanism, 5) Building a Muslim personality, 6) Building maturity IQ, EQ and SQ, 7) Applying theological backrest, rational, empirical and theoretical, and 8) Considering the culture. All proved positive and significant effects to the emotional intelligence of students studying at the least 1 (one) year at Islamic educational institutions in the Municipality of Bekasi measured through five indicators, namely: 1) Knowing the self emotional, 2) Managing emotions, 3) Self motivating, 4) Knowing emotions of others and 5) Establishing contact with other people. In more details, the findings of this study also indicate that school policies that build a learning management system on the basis of Qur'anic revelation 
and Hadith implemented in the regulations among others for reading the Qur'anic verses (tadarrus) before midday prayers congregatively, performing midday prayers altogather, fasting on Mondays and Thursdays, Dhubā prayer and reading Asmāul Husna a before the first hour of lessons. Fortunately, these have turned out to be perceived positively (agree) by learners. The characteristics of religious activities have been carried out regularly, orderly, and solemnly. This education management policy directly yielded positive results in emotional intelligence of students, especially in the ability of learners in reading and memorizing the Qur'an, the improvement of behavior of learners positively as they got more disciplined and orderly.The students also got high moral, especially in understanding all materials taught by teachers in the classroom, they are very enthusiastic about the new knowledge, especially those relate to result much benefits to human life. This policy also gives positive aspects to the ability of managing emotions in a positive way, so students are not easily provoked by acts of violence and other irregularities. They became more patient, showed a high level of empathy towards their friends who were experiencing trouble and did not hesitate to give a hand.

Management of Islamic education at the school environment Islamic educational institutions in the Municipality of Bekasi patterned theoanthropocentric implementation in the forms of school policy to the collection activities, such as the calls for berinfaq (giving alms and charity), keeping the environment clean and orderly, and to chant $d 0^{\circ} a$ along with greetings to their teachers in every lesson which begins at the class meeting. These religious forming behaviours were perceived agreement to follow by learners, as it is characterized by students' attitudes striving to obey the relious regulations (though not required). Theoanthrophocentric patterned policy provides very large impact on the emotional intelligence of students. They have the ability to be more sensitive and have concerns about their surrounding environment, showing affection to friends who are struggling, empathize and help friends who are in distress. In developing emancipatory attitude, management of Islamic education gives students the freedom to choose extra-curricular activities, to maintain order, to require keeping ablution when students enter the school ground and strict to schedule of becoming priests when pray together. Entrusted to other learners is also perceived positively (agree), this can be seen from the enthusiasm of the students in participating with extracurricular activities, student behaviors that limit the interaction with non mahram (because of keeping ablution) and democratic behavior in determining deliberation faith prayer in congregation. This regulation more responsibility behavior; promote deliberation in solving any problem, and create a high spirit of competition to be the best 
(achievement motivation). Wearing a skullcap (Caps) when performing obligatory prayers, using $S h a i^{-1} a$ compliant fashion, wearing uniforms that have been specified in the regulations. There was also to emulate the behaviors of the prophet Muhammad and recite $d b i k r$ after prayers, those are forms of implementation of developing a transformative mechanism in management education which is perceived positively in Islam. Kebijakan or policy was agreed by learners, which is characterized by subservience and performance. This regulation has positive influence on the emotional intelligence of students, especially in the ability to practice $5 \mathrm{~S}$ culture (smiles, greetings, greetings, polite, well mannered) at the school environment. There was also found the ability of learners to maintain good relations with local community in establishing a positive relationship with the school.

The findings of the research also show the management of Islamic education at the school environment aiming to the establishment of Muslim personalities outlined in the policy that requires activities to mentadaburi. The Quran. Wearing a cap during the flag raising ceremony on Mondays positively influences on the emotional intelligence of students, especially in the ability of learners who always try to improve themselves to become better persons and become a part of the community by giving a lot of benefits to other people.

Management of Islamic education at the school environment did also always workable in building intellectual maturity, emotional and spiritual learners which should be simultaneous, continuous and sustained in them through the implementation of regulations that require students to learn and practice English and Arabic in everyday life at the school particularly. This policy provided a positive impact. It is characterized by the attitude that comply with these regulations. The positive impact of the policy is evident from the increasing emotional intelligence of students, primarily on the ability of students to compete and continue to enhancement oftheir capabilities. Management of Islamic education at the school environment made by policy build on the basis of theological, rational, empirical and theoretical aspects have born regulations requiring students to participate in the improvement of the Qur'anic reading skills and practices, those perceived positive (agree) by students. It was characterized by high participation of students in religious activities such as MTQ, Tabfidz Quran competition, competition of Islamic propaganda, tadabbur Qur'an and others. This policy also provided positively to emotional intelligence of students, especially at high competitive ability and always striving to build themselvesto bebetter personalities. Management of Islamic education at the school environment also considers aspects of the local culture as a source of school rules so that the school management called the learners to participate with religious 
activities organized by the community. This policy is very positive response (as agreed by learners, it is seen from their enthusiasm and high participation involving with religious activities performed by the local community, such as the birthday of the Prophet Muhammad's commemoration, the slaughter of sacrificial cattles, Celebration of 1 Muharram, and so forth. These regulations have positive influences on the emotional intelligence of students, especially in their abilities to stay in touch and build a relationship with the community, providing assistance to those who were in need, develop an attitude of solidarity among people in the surrounding environment and strive to provideas much of benefits to them.

The influence of Islamic education management at the school environment provided a very big impact, considering that the school environment's implementation on the educational processes more systematic, well planned and controllable. The process of education at the school environment refers to the curriculum and teaching methods that have been defined and supported byschool's adequate learning infrastructure. The Indonesia's Government and education experts always do to develop learning and teaching processesat schools, both the development of the curriculum, teaching methods and evaluation of the effectiveness of the learning process. The Government's commitment to improve the quality of education is also demonstrated by the President Susilo Bambang Yudhoyono on celebration of the National Awakening Day on May 20, 2011.The President said the orientations of character education in Indonesia are: 1) Build Indonesian human morals and good behavior, 2) Develop intelligent and rational community, 3) Train the Indonesian people to be innovative and always coming along with the progress, 4) Strengthen the spirit of "Must Could" a solution to any problems, 5) Build Indonesian people to become a true patriot, love the nation, the state and the homeland. People's committed to improve the quality of human resources is to follow the internalization of the 18 valuesthat should be cultivated in the educational processes, namely: (1) religiousity, (2)honesty, (3) tolerance, (4) discipline, (5) working-hard, (6) creativity, (7) independence, (8) democracy, (9) curiosity, (10) the spirit of nationality, (11) love of homeland, (12) appreciating achievement, (13) friendly/communicative, (14) loving peace, (15) fond of reading, (16) care the environment, (17) social care, and (18) responsibility (Rumah Inspirasi Online, October 4, 2011). In the process of education, the school environment serves as 1) mentoring private consolidation efforts towards culture, 2) teaching as an attempt of mastering knowledge, and 3) training as an effort to the improvement of skills, more specifically, the school environment also need to serve for: a) Assisting learners interaction with the environment (physical, social, cultural), b) teaching general behavior, and c) 
selecting or preparing certain people to perform certain functions (Tirtarahardja, 2000, p. 42).

\section{CONCLUSION}

The research results indicate that learners perceive positively (agree) to all Islamic education management policies implemented at the school environment, in which perception is reinforced by their behaviors showing agreementas they always adhere to all school policies. The results of this study also showed a positive and significant influence of Islamic education management at the school environment to the emotional intelligence of students in Islamic educational institutions at Bekasi City, West Java, Indonesia that is equal to $0.907 \%$. These results can be interpreted that if the management of Islamic education at the school environment enhanced, the effectiveness of the implementation of one percent of the emotional intelligence of students will increase by $0.907 \%$. The results of this study also on answered the cause of the rise of students' negative behaviors over the years. The management of Islamic education at the school environment could actually be the main solution of the system of education in the school environment as a preventive and anticipatory on deviant behavior of learners. Management of Islamic education in the school environment can also work together in its implementation with 18 indicators of character education at schools starting from element to element of the classroom. Efforts to foster religious behaviors in the management of Islamic education of the school environment can be done in the forms ranging from celebrating religious holidays, providing worship facilities for the whole school community and to provide an opportunity for the entire school community in implementing the trust and confidence of worship in complementary with their school components respectively. The management of Islamic education atthe classroom environment can be carried out by getting used to pray before starting lessons or for Muslimsthey can do tadarrusan (Qur'anic recitation) to read the meaning of the verses so as to get better understanding on the meaning consisting inthe Holy Qur'an. Emotional intelligence of the learners can be grown by the impelentation of the management itself, the impacts supported by policies, methods and adequate infrastructure of the Islamic education institutions. Efforts to building honest behaviors, for example, can be fostered through the provision of canteen of honesty, which urged to hand over the goods that do not belong to them in the case they find something, provide a place to put the belongings for others which were found. Applying the same treatment should also be to all learners without discriminatory in any reasons, exemplifying discipline, empathy, and support to each other for the sake ofthe progress of all parties. 


\section{BIBLIOGRAPHY}

Ali, N. Syatibi, I., (2009). Manajemen Pendidikan Islam Ikbtiar Menata Kelembagaan Pendidikan Islam, Bekasi: Pustaka Isfahan.

Antonio, M. S., (2011). Muhammad SAW The Super Leader Super Manajer, Jakarta: pro LM Centre Tazkia Publishing.

Azwar, S., (2011). Tes Prestasi, Yogyakarta: Pustaka Pelajar.

Baharuddin, Makin, M. Manajemen Pendidikan Islam Transformasi Menuju Sekolah/Madrasah Unggul, Malang: UIN. Maliki Press.

Bell, P. A., et al., (1996) Environmental Psychology. Foth Woth: Holt Rinehart and Winston Inc.

William, C. (n.d.) Moral Lingkungan Hidup. Yogyakarta: Kanisius.

Cushner, K., McClelland, A.Safford, P., (2009) Human Diversity In education, New York: Mc Graw-Hill.

Fauzi, I., (2012). Manajemen Pendidikan Ala Rosululloh, Jogjakarta: Ar-Ruzz Media.

Goleman, D., (2005). Kecerdasan Emosi untuk Mencapai Puncak Prestasi, tr, A. T. K. Widodo. Jakarta: Gramedia Pustaka Utama.

Hahlawi, A. A., (1995). Pendidikan Islam di Rumah Sekolab dan Masyarakat, Jakarta: Gema Insani.

Hamid, H., (2013). Pengembangan Sistem Pendidikan di Indonesia, Bandung: Pustaka Setia.

Nasih, A. M., Kholidah, L. N., (2009). Metode dan Teknik Pembelajaran Pendidikan Agama Islam, Bandung: Refika Aditama.

Noll, J. W. (2008). Taking Sides: Clashing Views on Education Issues, Amerika: McGraw Hill.

Qomar, M., (2009). Manajemen Pendidikan Islam, Jakarta: Erlangga.

Rumah Inspirasi., (2011). 18 Nilai Pendidikan Karakter Bangsa, 4 October 2011

Syafaruddin, Nurgayah, Mahariah, et. al., (2006). Ilmu Pendidikan Islam (melejitkan potensi budaya umat), Jakarta: Pustaka Utama.

Snell, S., Bohlander, G., (2010). Principle of Human Resource Management. 15th ed. South-Western Cengage Learning.

Tirtarahardja, U. La Sulo, S. L., (2005). Pengantar Pendidikan. Jakarta: Rineka Cipta. 